\title{
HUBUNGAN PREEKLAMPSIA DENGAN KEJADIAN ASFIKSIA NEONATORUM DI RSUD KOTA MATARAM TAHUN 2017
}

\author{
Andi Setiawan Tahang*, Muhammad Nauval**, Niky Reisiya Afna*** \\ Fakultas Kedokteran Universitas Islam Al-Azhar \\ J1. Unizar No.20 Turida Mataram
}

\begin{abstract}
ABSTRAK
Preeklampsia adalah salah satu faktor yang menyebabkan terjadinya kematian pada wanita hamil di Rumah Sakit Umum Daerah Kota Mataram. Beberapa wanita hamil yang mengalami preeklmpsia juga dapat mempengaruhi janin yang akan menyebabkan terjadinya asfiksia neonatorum.

Tujuan : Tujuan dari penelitian ini adalah untuk mengetahui hubungan antara preeclampsia dengan kejadian asfiksia neonatorum Rumah Sakit Umum Daerah Kota Mataram tahun 2017.

Metode penelitian yang digunakan bersifat analitik dengan rancangan penelitian cross sectional. Subyek penelitian adalah wanita hamil yang memiliki diagnosis preeklampsia di rekam Medis Rumah Sakit Umum Daerah Kota Mataram sebanyak 100 orang.

Studi ini menggunakan 100 orang sampel wanita hamil Di Rumah Sakit Umum Daerah Kota Mataram pada tahun 2017 dengan usia rata-rata $32( \pm 7,012)$ tahun. Sebanyak 35 orang melahirkan secara SC, dan 35 lainnya melahirkan secara normal. 67 orang subjek mengalami preeclampsia dan 45 diantaranya melahirkan bayi asfiksia. Hasil analisis uji Chy Square diperoleh nilai signifikan sebesar 0,008 atau $\mathrm{p}<0,005(0,008<0,005)$.

Terdapat hubungan antara preeklampsia dengan kejadian asfiksia neonatorum di Rumah Sakit Umum Daerah Kota Mataram pada tahun 2017 dengan koefisien kontingensi sebesar 1,705 yang menunjukkan kekuatan hubungan yang cukup bermakna.
\end{abstract}

Kata Kunci : Preeklampsia, Asfiksia.

\section{PENDAHULUAN}

Preeklampsia merupakan kelainan yang ditemukan pada waktu kehamilan yang biasanya terjadi setelah usia kehamilan 20 minggu sampai 48 jam setelah persalinan. Preeklampsia pada ibu hamil dapat mengakibatkan pertumbuhan janin terhambat, pendarahan serebral, gagal jantung, ginjal, hati, trombolisme, gangguan pembekuan darah, dan trauma. Pada bayi dengan ibu preeclampsia dapat mengakibatkan prematuritas, Intrauterine Growth Retardation (IUGR), gawat janin, kematian janin dalam rahim sampai dengan kematian pada saat kelahiran (Winkjosastro, 2007).

$$
\text { Menurut World Health }
$$

Organization (WHO), sekitar 830 wanita meninggal setiap harinya akibat komplikasi dalam kehamilan (WHO, 2016). Penyebab kematian ibu terbanyak adalah perdarahan (25\%), infeksi (15\%), preeklampsi (12\%), abortus (13\%), dan persalinan lama (8\%) (Pathwardan, 2016). Di Afrika, dari 7.702 pasien yang datang ke bangsal ginekologi, 172 merupakan pasien preeklampsi (Vata, 2015). Didapatkan pula hasil berdasarkan yang melaporkan bahwa terdapat 30 dari 218 $(13,8 \%)$ wanita hamil yang mengalami hipertensi (Dantas, 2013).

Preeklampsia pada ibu salah satunya akan menyebabkan terjadinya asfiksia pada bayi baru lahir. Asfiksia bisa 
terjadi karena gangguan perfusi uteroplasenter akibat vasospasme dan kerusakan arteri spiralis pada saat dalam kandungan. Selain itu asfiksia pada bayi juga dapat dipicu oleh gangguan oksigenasi oleh karena pengobatan sedativum yang diberikan pada ibu. Hal ini menyebabkan hipovolemi, vasospasme, penurunan perfusi uteroplasenta dan kerusakan sel endotel pembuluh darah plasenta, jika tidak dilakukan pencegahan dari awal pada ibu atau tidak dilakukan penanganan segera pada kejadian asfiksia maka akan berdampak fatal pada bayi yang dilahirkan yaitu meningkatkan angka morbiditas dan mortalitas (Sarwono Prawiraharjo, 2009).

Asfiksia Neonatorum menurut IDAI (Ikatan Doker Anak Indonesia) adalah kegagalan nafas secara spontan dan teratur pada saat lahir atau beberapa saat setelah lahir (Prambudi,2013).

Menurut Harnowo (2013) dari hasil Survei Demografi dan Kesehatan Indonesia (SKDI) tahun 2012 lalu menemukan bahwa sekitar lebih dari 80.000 bayi baru lahir meninggal dunia saat berusia kurang dari sebulan. Hampir $43 \%$ kematian bayi dibawah usia 1 tahun terjadi pada 28 hari pertama kehidupan. Angka kematian bayi di Indonesia saat ini berkisar hingga 32 per 1000 kelahiran hidup. Diangka ini, 19 per 1000 terjadi pada masa neonatal sejak lahir sampai usia 28 hari. Penyebab kematian terbanyak disebabkan oleh masalah neonatal seperti asfiksia (27\%), BBLR (29\%), serta infeksi neonatus (Bararah, 2012).

Pada tahun 2015, AKB NTB mengalami peningkatan sebanyak 16 kasus dari tahun 2014. Peningkatan ini disebabkan oleh komplikasi kehamilan yang belum ditangani sebesar 9,09\% (Dinas Kesehatan Provinsi Nusa Tenggara Barat, 2012).

Dengan demikian asfiksia adalah keadaan dimana bayi tidak dapat segera bernafas secara normal. Bayi dengan riwayat gawat janin sebelum lahir, umumnya akan mengalami asfiksia pada saat dilahirkan. Masalah ini erat hubungannya dengan gangguan kesehatan ibu hamil, kelainan tali pusat, atau masalah pada bayi selama atau sesudah persalinan.

Tingginya angka kematian janin dalam kandungan ini sebenarnya dapat diatasi dengan Antenatal Care yang teratur, sehingga jika terdapat komplikasi maka akan dapat diatasi dengan cepat. Berdasarkan data tersebut, maka peneliti ingin mengetahui bagaimana hubungan preeklampsia pada ibu hamil dengan kejadian asfiksia neonatorum di RSUD Kota Mataram. 


\section{METODE PENELITIAN}

Jenis penelitian ini bersifat analitik dengan rancangan penelitian cross sectional. Tempat penelitian dilaksanakan di Rumah Sakit Umum Daerah Kota Mataram. Waktu penelitian dilaksanakan pada bulan Mei 2017.

Populasi dalam penelitian ini adalah seluruh ibu yang melahirkan di RSUD Kota Mataram tahun 2017. Jumlah sampel yang digunakan adalah sebanyak 100 orang. Pengambilan data dilakukan dengan penelusuran rekam medis pasien yang melahirkan di Rumah Sakit Umum Daerah Kota Mataram.

Analisis deskriptif dilakukan untuk menilai karakteristik umum pasien preeklampsia. Sedangkan analisa statistic menggunakan chi square untuk menilai hubungan dan prevalence risk antara preeclampsia dengan asfiksia neonatorum.

\section{HASIL DAN PEMBAHASAN PENELITIAN}

Penelitian ini dilakukan di Rumah Sakit Umum Daerah Kota Mataram dengan jumlah 100 sampel. Subjek preeklampsia sebanyak 63 orang $(63 \%)$ dan 33 orang (33\%) tidak preeklampsia dengan karakteristik sampel sebagai berikut:

Tabel 1.1 Karakteristik Usia Sampel

\begin{tabular}{|c|c|c|c|c|}
\hline Usia Ibu (tahun) & Preeklampsia & $\begin{array}{c}\text { Tidak } \\
\text { Preeklampsia }\end{array}$ & $\begin{array}{c}\text { Jlh } \\
(\mathbf{n})\end{array}$ & Presentase (\%) \\
\hline$<20$ & 1 & 5 & 6 & 6 \\
\hline $20-35$ & 21 & 9 & 30 & 30 \\
\hline$>35$ & 45 & 19 & 64 & 64 \\
\hline Total & 67 & 33 & 100 & 100 \\
\hline
\end{tabular}

Sumber : data sekunder RS Kota Mataram tahun 2017

Pasien dengan klasifikasi usia $<20$ tahun terdapat sebanyak 6 orang $(6 \%)$ diantaranya terdapat ibu preeklampsia 1 orang (1\%), pasien dengan usia 20-35 tahun sebanyak 30 orang (30\%) dan 21 orang $(21 \%)$ diantaranya mengalami preeklampsia dan pasien dengan usia $>35$ tahun sebanyak 64 orang ( $64 \%$ ) dan 45 orang $(45 \%)$ diantaranya mengalami preeklampsia.

Tabel 2.1 Karakteristik Asfiksia

\begin{tabular}{ccc}
\hline Asfiksia & Jumlah (n) & Presentase (\%) \\
\hline Asfiksia & 58 & 58,0
\end{tabular}


Tidak asfiksia

Total

100

100

Sumber : data sekunder RS Kota Mataram tahun 2017

Dari 100 responden terdapat 58

orang $(42 \%)$ tidak mengalami asfiksia.

orang (58\%) mengalami asfiksia dan 42

Tabel 3.1 Analisa Univariat

\begin{tabular}{|c|c|c|c|}
\hline Variabel & Asfiksia & Tidak Asfiksia & Jlh (n) \\
\hline Preeklampsia & 45 & 22 & 63 \\
\hline $\begin{array}{c}\text { Tidak } \\
\text { Preeklampsia }\end{array}$ & 13 & 20 & 33 \\
\hline Total & 58 & 42 & 100 \\
\hline
\end{tabular}

Sumber : data sekunder RS Kota Mataram tahun 2017

Dari 100 responden, 67 diantaranya mengalami preeklampsia dan 33 lainnya tidak mengalami preeklampsia. Dengan individu yang sama, didapatkan pula hasil bahwa dari 100 responden yang diteliti, didapatkan 58 orang yang melahirkan bayi asfiksia, sementara 42 orang tidak melahirkan bayi asfiksia.

Tabel 4.1 Hasil Analisis Bivariat

\begin{tabular}{|c|c|c|c|c|c|c|c|c|c|c|}
\hline \multirow{3}{*}{ Preeklampsia } & \multicolumn{4}{|c|}{ Asfiksia } & & \multirow[t]{2}{*}{ JML } & \multirow[t]{2}{*}{ P- } & \multirow{3}{*}{$95 \% \mathrm{Cl}$} & \multirow{3}{*}{ PR } & \multirow{3}{*}{ C } \\
\hline & \multicolumn{2}{|c|}{$\mathrm{Ya}$} & \multicolumn{2}{|c|}{ Tidak } & & & & & & \\
\hline & $\mathrm{N}$ & $\%$ & $\mathrm{~N}$ & $\%$ & $\mathrm{~N}$ & $\%$ & value & & & \\
\hline \multirow[t]{2}{*}{ Ya } & 45 & 67,2 & 22 & 32,8 & 67 & 100 & \multirow{3}{*}{0,008} & 1.082 & & \\
\hline & & & & & & & & & 1,705 & 0,256 \\
\hline Tidak & 13 & 39,4 & 20 & 60,6 & 33 & 100 & & 2,688 & & \\
\hline Jumbh & 58 & 58 & 42 & 42 & 100 & 100 & & & & \\
\hline
\end{tabular}

Sumber : data sekunder RS Kota Mataram tahun 2017

Berdasarkan data yang telah hubungan antara kedua variable yaitu didapat oleh peneliti, maka dilakukan uji preeklampsia dan asfiksia di Rumah Sakit statistik Chi Square menggunakan SPSS Umum Daerah Kota Mataram. Selain itu, 16 dan diperoleh hasil nilai $p$ adalah dapat tergambarkan nilai Prevalence 0,008 yang menyatakan bahwa terdapat Ratio (PR) sebesar 1,705 dengan nilai 
lower dan upper dari Confident Interval (CI) menggunakan tingkat kepercayaan 95\% yaitu 1,082-2,688 dan koefisien Contigency $\quad 0,256 \quad(\mathrm{CC}=0) \quad$ dapat menyatakan bahwa $\mathrm{H}_{0}$ penelitian ini ditolak.

Terdapatnya hubungan yang signifikan antara preeklampsia dengan kejadian asfiksia ini sesuai dengan yang dikemukakan oleh Suci (2013) bahwa 90,8\% ibu yang preeclampsia melahirkan bayi yang asfiksia. juga sesuai dengan penelitian yang dilakukan oleh sunarsih (2014) yang menyebutkan bahwa 56,2\% asfiksia disebabkan oleh preeklampsia (sunarsih, 2014). Hal serupa juga diutarakan dalam penelitian yang dilakukan oleh Hodgins bahwa preeklampsia berkontribusi besar terhadap terjadinya asfiksia neonatorum (Hodgins, 2015).

\section{KESIMPULAN}

Berdasarkan hasil dan pembahasan mengenai hubungan preeklampsia dengan kejadian asfiksia di Rumah Sakit Umum Daerah Kota Mataram, dapat diambil kesimpulan sebagai berikut :

1. Dari hasil penelitian di Rumah Sakit Umum Daerah Kota Mataram, diperoleh nilai $p$ sebesar 0,008 hal ini menunjukan bahwa preeklampsia berhubungan signifikan terhadap terjadinya asfiksia. Hal ini dapat berarti bahwa $\mathrm{H}_{0}$ ditolak dan $\mathrm{H}_{1}$ diterima.

2. Rasio prevalensi dari penelitian ini adalah 1,705. Artinya bahwa ibu preeklampsia memiliki resiko sebanyak 1,705 kali untuk melahirkan bayi yang asfiksia.

3. Dari 100 sampel yang diteliti, terdapat 67 (67\%) ibu mengalami preeklampsia dan 33 (33\%) ibu tanpa preeklamsia.

4. Dari 100 sampel yang diteliti, terdapat $58(58 \%)$ bayi mengalami asfiksia dan $42(42 \%)$ lainnya tidak mengalami asfiksia.

\section{DAFTAR PUSTAKA}

Alwi, Hasan. 2007. KBBI, edisi ketiga. Kedokteran EGC. Jakarta: balai Pustaka dan KB.

American College Obstetricians and Gynecolysts (ACOG). 2013. Clasification Hypertensive Disorders in : Hypertention in Pregnancy, p: 13-14.

Aminullah, A. 2002. Asfiksia Neonatorum. Dalam; Ilmu Kebidanan, Yayasan Bina Pustaka Sarwono Prawiroharjo, Jakarta, hal. 711.

Bankowski BJ, Hearne AE, et al.2002. The Johns Hopkins manual of Gynecology and Obstetrics2nd edition (May 2002): The Johns Hopkins University Department By Lippincott Williams \& Wilkins Publishers US, 519-521.

Bararah, 2012. Penyebab Kematian Neonatal. kompas.com/penyebab kematian neonatal di akses tanggal 28 maret 2018.

Cunningham FG, Leveno KJ, Bloom SL, Hauth JC, Rouse DJ, Spong CY, 
et.al. 2012. Neonatus

Obstetri Williams. Terjemahan

Brahm U. Edisi 23, Vol. 1. EGC. Jakarta, hal. 617.

Dantas, Melo. et al. 2013.Preeclampsia is associated with increased maternal body weight in a northeastern Brazilian population.Diunduh di https://www.ncbi.nlm.nih.gov/pmc/ articles/PMC4231463/

Departemen Kesehatan RI. Profil Kesehatan Indonesia 2009. Jakarta : Depkes RI 2009. http:/depkes.go.id./en/downloads. diakses tanggal 15 April 2018.

Dinas Kesehanan Provinsi Nusa Tenggara Barat. Provil Kesehatan Provinsi Nusa tenggara Barat Tahun 2012. Mataram 2013.

Hacker , N. F., George, M., 2004. Esensial Obstetri dan Genikologi Ed. 2. Jakarta: Penerbit Hipokrates, pp: 164;179-91;27586.

Hanifa, Wiknjosastro. 2008. Ilmu Kandungan. Edisi 2. EGC : Jakarta.

https://www.acog.org/ /media/Ta sk\%20Force\%20and\%20Work\% 20Group 20Reports/public/Hypertensionin Pregnancy.pdf

Harnowo, Putro Agus. 2013. P3K: Pwertolongan Pertama dan Penanganan Darurat. Itokindo.

Manuaba, IBG, dkk. 2010. Penyulit pada Neonatus. Ilmu Kebidanan, Penyakit Kandungan, dan KB. EGC. Jakarta, hal. 421.

Mochtar, R. 2010. Sinopsis Obstetri Fisiologi Patologi, Edisi III, EGC, Jakarta.

Notoadmojo. 2010. Metodologi Penelitian Kesehatan. Jakarta: Rineka Cipta.

Prambudi, R. 2013. Penyakit pada Neonatus. Dalam; Neonatologi
Praktis. Anugrah Utama Raharja.

Cetakan Pertama. Bandar

Lampung, hal. 57 - 62.

Prambudi, R. 2013. Prosedur Tindakan Neonatusi. Dalam; Neonatologi Praktis. Anugrah Utama Raharja. Cetakan Pertama. Bandar Lampung, hal. 115 - 31 .

Prawirohardjo, S., 2009. Ilmu Kebidanan, Jakarta, PT Bina Pustaka.

prawirohardjo S. 2010. Ilmu Kebidanan. Jakarta: PT. Bina Pustaka Sarwono prawirohardjo.

Saifuddin A.B., 2009.Buku Acuan Nasional Pealayanan Kesehatan Maternal dan Neonatal.

Jakarta: Yayasan Bina Pustaka Sarwono Prawirohardjo.

Saifuddin, AB. 2009. Masalah Bayi Baru Lahir. Dalam; Buku Acuan Nasional Pelayanan Kesehatan Maternal dan Neonatal. Bina Pustaka Sarwono Prawiroharjo. Cetakan Kelima. Jakarta, hal. 347 54.

Sugiyono. 2012. Metode Penelitian Pendidikan Kuantitatif Dan Kualitatif. Bandung: Alfabeta.

Vata, Kumar. Et al. 2015. Assessment of prevalence of preeclampsia from Dilla region of Ethiopia.Diunduh di

https://www.ncbi.nlm.nih.gov/pmc/ articles/PMC4690301/

Winkjosastro H. 2007. Ilmu Kandungan. Jakarta: Yayasan Bina Pustaka.

Wiknjosastro H.2009. Ilmu Kebidanan. Edisi ke-4 Cetakan ke-2. Jakarta: Yayaan Bina Pustaka Sarwono Prawirohardjo.

World Health Organization (WHO). 2010. Trends in Maternal Mortality 1990 to 2008, The World Bank.

World Health Organization (WHO). 2011. WHO Recommendations for Prevention and Treatment of Preeclampsia and Eclampsia, p: 4-5 